Open Access

\title{
Erratum to: The significance of NTR1 expression and its correlation with $\beta$-catenin and EGFR in gastric cancer
}

Zhiyi Zhou', Jiaming Xie ${ }^{1}$, Ying $\mathrm{Cai}^{2}$, Shudong Yang ${ }^{2}$, Ying Chen ${ }^{2}$ and HaoRong Wu ${ }^{\text {1* }}$

The original version of this article unfortunately contained a mistake. In the author list, the name of author Zhiyi Zhou was incorrectly spelled. The correct spelling has been published in this Erratum.

\section{Author details}

'Department of General Surgery, The Second Affiliated Hospital of Soochow University, Suzhou 215004, China. ${ }^{2}$ Department of Pathology, Wuxi People's Hospital Affiliated to Nanjing Medical University, Wuxi 214023, China.

Received: 9 September 2015 Accepted: 9 September 2015

Published online: 17 September 2015

\footnotetext{
*Correspondence: wuhaorong666@126.com

${ }^{1}$ Department of General Surgery, The Second Affiliated Hospital of Soochow University, Suzhou 215004, China
}

Submit your next manuscript to BioMed Central and take full advantage of:

- Convenient online submission

- Thorough peer review

- No space constraints or color figure charges

- Immediate publication on acceptance

- Inclusion in PubMed, CAS, Scopus and Google Scholar

- Research which is freely available for redistribution

Submit your manuscript at www.biomedcentral.com/submit 